J. Product. \& Dev., 26(3):433-446(2021)

\title{
EFFECT OF SOME SALTS ON THE MYCELIAL GROWTH AND SPORE GERMINATION OF FUNGI CAUSED FRUIT ROT OF SWEET PEPPER POST-HARVEST DISEASES PATHOGENS
}

\author{
Amira M. Tawfik, Ali M. Koriem, Sayed E. Younis and M. I Elian \\ Faculty of Technology \& Development, Zagazig University, Egypt. \\ Corresponding author E-mail: amt2222@yahoo.com Mobile: +201062951792
}

\section{ABSTRACT}

The paper aimed to inhibit evaluate the effects of some salts as natural products on postharvest diseases of sweet pepper fruits under the laboratory conditions and evaluate their effects on the development and suppression of these diseases. To achieve these aims, four different salts i.e. sodium carbonate, sodium bicarbonate, potassium nitrate and calcium chloride was applied at four concentrations, 1, 2, 3 and 4\% (w/v). Salt solutions were tested on the mycelial growth and spore germination of Ulocladium chartarum, Aspergillus niger, Fusarium semitectum and Geotrichum candidum. Seven days post incubation, mycelial growth of the tested fungi were completely inhibited by the used salt solutions. Generally, the obtained results indicate a clear impact for most used salts solutions especially sodium salts.

Finally, the optimum concentrations of salts under the experiments study conditions for inhibiting of growth of Ulocladium chartarum, Aspergillus niger, Fusarium semitectum, and its spores. Geotrichum candidum were $4,3,3,3 \%(w / v)$ for sodium carbonate, sodium bicarbonate, potassium nitrate and calcium chloride, respectively.

Conclusively, the optimum concentrations of salts in this study for inhibiting growth of some fungi were 4, 3, 3, 3\% (w/v) for sodium carbonate, sodium bicarbonate, potassium nitrate and calcium chloride, respectively.

Keywords: Mycelial growth; Spore germination; salts; sweet peppers, fruits rot.

\section{INTRODUCTION}

The sweet pepper (Capsicum annuum L.) is considered an important vegetable crop worldwide. It is a vegetable crop belonging to the family 
Solanaceae and genus Capsicum (Berke, 2002). Pepper contains phytochemicals thatsupport in the protection of many diseases e.g., cancer, stroke and others when eaten in diets (Ademoyegun et al., 2011). It is essential for food, medicinal and industrial crops (Ashilenje, 2013). The pepper extract also used as a botanical pesticide for controlling insect and diseases of economic crops within organic agriculture systems. It is used in pickles, for flavoring sauces and in canned products. They are also used for confectionery products like bread, meat pie, burger (Ekhuemelo et al., 2018). It can be consumed in many colors, is rich in both hydrophilic antioxidants e.g., vitamin $\mathrm{C}$, lipophilic ones e.g., carotenoids or/and vitamin E (Ilić et al., 2012) and with potential health-promoting properties (Bae et al., 2012). Additionally, it has a high content of ascorbic acid compared to other vegetables and fruits. After the maturity stage of pepper, the major limiting factor is its relatively short shelf life (one to two weeks) which requires the use of air rather than sea transport for the export of peppers to lucrative distant markets (Maalekuu et al., 2003).

Many salts were applied to inhibit fungi growth, i.e. sodium bicarbonate, sodium benzoate, sodium metabisulphite, and potassium metabisulphite...etc. Sodium bicarbonate (SBC). It can suppress postharvest anthracnose disease of papaya. Sodium bicarbonate at various concentrations $(0,1,1.5,2,2.5$, and $3 \%$ w/v) was used as treatment against mycelial growth and spore germination of Colletotrichum gloeosporioides. One week post incubation, mycelial growth was completely inhibited by SBC 3\%, which was statistically similar with 2 and $2.5 \%$ SBC (99.5 and 96.5\% inhibition, respectively) (Hasan et al., 2012). Bicarbonate and carbonate salts of sodium and potassium have been shown to inhibit fungal pathogens of fruits, field crops, vegetables and ornamentals (DePasquale et al. 1990; Ziv and Zitter 1992; Punja and Gaye 1982; Aharoni et al. 1997; Palmer et al. 1997; Campanella et al. 2002; Palou et al. 2002; Arslan et al. 2009; Erper et al. 2011; Latifa et al. 2011).

In a related context, Ajith and Lakshmidevi (2011) illustrated that using sodium benzoate, sodium metabisulphite and potassium metabisulphite at $1 \mathrm{mg}$ $\mathrm{ml}^{-1}$ concentration completely inhibited the conidial germination and mycelial growth whereas, potassium nitrate inhibited the conidial germination and mycelial growth by 70 and $12 \%$ respectively. Another salt such as ammonium chloride, ammonium tartrate, calcium chloride dehydrates, potassium dihydrogen phosphate, potassium iodide and sodium sulphate increased sporulation of $H$. solani at the concentration of $0.1 \mathrm{M}$. Sodium benzoate was also the most effective compound in spores germination inhibiting (100\%) for both fungi, followed by 
potassium iodide (93\%) for $F$. solani and ammonium acetate $(88 \%)$ for $H$. solani., respectively.

Other salts significantly enhanced the mycelial growth of the fungus as potassium acetate, potassium chloride, potassium nitrate, potassium phosphate dibasic, sodium chloride, sodium sulfate and trisodium phosphate while diammonium phosphate had no significant effect (Turkkan, 2013). Moreover, ElMougy \& Abdel-Kader (2009) indicated that the application of sodium bicarbonate or calcium chloride significantly reduced the early blight incidence and severity by increasing their concentrations. Their most effective concentration was $30 \mathrm{mg} / \mathrm{ml}$ reduced the disease incidence by 50 and $62.4 \%$, respectively (ElMougy \& Abdel-Kader, 2009). Considerable interest in the use of sodium bicarbonate $\left(\mathrm{NaHCO}_{3}\right)$ and potassium bicarbonate $\left(\mathrm{KHCO}_{3}\right)$ for controlling various fungal diseases of plants (Karabulut et al., 2003; Smilanick et al., 2006). Lindsay (1985) indicated that bicarbonates are widely used in the food industry also, Ziv and Zitter (1992) noticed that it was effective in controlling several fungal diseases in cucumber plants. Spraying plants with $\mathrm{NaHCO}_{3}$ solution provided good control of several plant diseases (Horst et al., 1992; Arimoto et al., 1997; Palmer et al., 1997; Janisiewicz and Peterson, 2005). Additionally, the use of $\mathrm{KHCO}_{3}$-spraying solution provided the most effective protection against plant diseases (Smilanick et al., 1999; Smilanick et al., 2006). Sodium and/or potassium bicarbonate combined with oil were effective in controlling plant diseases (Horst et al., 1992; Ziv and Zitter 1992). Calcium chloride $\left(\mathrm{CaCl}_{2}\right)$ suppressed the growth of the citrus mold pathogen Penicillium digitatum (Droby et al., 1997). Also, calcium chloride effectively reduced silver scurf lesions on potato tubers, but not sporulation of Helminthosporium solani. It is known that the addition of calcium chloride can also improve the activity of biocontrol agents (McLaughlin et al., 1990; Droby et al., 2003).

Therefore, the objectives of this study were to evaluate the effects of some salts as natural products in vitro against postharvest diseases of sweet pepper fruits and evaluate their effects on the development and suppression of these diseases.

\section{MATERIALS AND METHODS}

\section{Plant materials:}

One hundred sweet pepper fruits were random collected from local markets of four cities at Elsharquia governorate as following: Abou Hammad, Belibes, El Zagazig and Elashir min Ramadan during the two successful seasons of 2016/2017 and 2017/2018. The collected sweet pepper fruits were kept in 
paper bag and transferred into Plant Pathology Laboratory, Facility of Technology \& Development, Zagazig University, Egypt. Then fruits were incubated at $25-28{ }^{\circ} \mathrm{C}$ for one week. The rotted fruits of sweet pepper were classified into the different groups according to the type and colour of rots. The percentage of rotted fruits due to the different causal agents was calculated and recorded.

\section{Isolation and identification of the fungal organisms:}

The infected portion of the pepper fruits was cut under aseptic conditions into small bits of $5 \mathrm{~mm}$ into a sterile dish with the aid of scissors which was flamed over a Bunsen burner flame and dipped inside methylated spirit (Fawole and Oso, 1988). The fruits pieces were sterilized within $70 \%$ ethanol then took placed centrally on Petri dishes containing solidified potato dextrose agar (PDA). Developing fungal isolates were purified using either a single spore method and/or hyphal tip technique suggested by Lilly and Barnett (1951). The purified isolated fungi were identified according to their morphological fractures using the description of Barnett and Hunter (1998). The isolated fungi were maintained on PDA slant, kept in the refrigerator at $5-8{ }^{\circ} \mathrm{C}$ and sub-cultured till used. The identification was confirmed at Disease Survey and Mycology Department, Plant Pathology Institute, Agricultural Research Center, Egypt.

\section{Salts used:}

Carbonate and bicarbonate of sodium, potassium nitrate, and calcium chloride were purchased from Merck Chemicals (Merck, Germany), Egypt as presented in Table (1).

Table (1): The used chemical salts in the experiment.

\begin{tabular}{lcc}
\hline \multicolumn{1}{c}{ Name of salt } & Chemical formula & Molecular weight \\
\hline Sodium carbonate & $\mathrm{Na}_{2} \mathrm{CO}_{3}$ & 105.99 \\
Sodium bicarbonate & $\mathrm{NaHCO}_{3}$ & 84.01 \\
Potassium nitrate & $\mathrm{KNO}_{3}$ & 101.10 \\
Calcium chloride & $\mathrm{KCl}$ & 110.98 \\
\hline
\end{tabular}

\section{Effect of salts on mycelial growth of fungi:}

The tested fungi were grown on PDA un-amended (control) or amended with the tested salts at $24{ }^{\circ} \mathrm{C}$ using PDA agar disks (diameter $=5 \mathrm{~mm}$ ) of actively growing mycelium of $F$. solani and $H$. solani, were used to inoculate the plates. For each plate, colony diameter was determined one-week post incubation. 
Colony diameter was measured as the average of the longest diameter $(\mathrm{cm})$ and the shortest diameter. Inhibition of mycelial growth (IMG) was calculated using the follows equation.

$\mathrm{IMG}=$ control radial growth - salt amended radial growth control radial

Three replicates were used.

$$
\text { growth } \times 100 \quad \text { [Eq. 1] }
$$

\section{5 . Effect of salts on spore germination:}

Spore suspensions of each pathogen ( $1 \mathrm{ml}$; 9X 105 spore's $\left.\mathrm{ml}^{-1}\right)$ were placed in micro-tubes containing $5 \mathrm{ml}$ of Potato Dextrose Broth (PDB) amended with the tested salt or untreated (control). The $\mathrm{pH}$ of PDB varied with the used salt and was not changed unless stated otherwise. Micro-tubes were incubated at $24{ }^{\circ} \mathrm{C}$ for one day. The germination of spores was determined using hemocytometer. Spores with germ tubes at least half the length of the spore were considered as germinated. Inhibition of spore germination (ISG) was calculated with the following equation:

$\mathrm{ISG}=$ control spore germination - salt amended spore germination control spore germination $\times 100$ [Eq. 2]

Three replicates were used.

\section{Statistical analysis:}

Statistical analyses of all experimental data were done using the statistical software SAS package (SAS Institute, 2002; available online), all comparisons were first subjected to one-way analysis of variance (ANOVA).

Significant differences between treatment means were determined using Duncan's multiple range test at $\mathrm{P}<0.05$ as the level of the significance (Duncan, 1955).

\section{RESULTS AND DISCUSSIONS}

The obtained results present in Table (2) indicated a clear effect of tested salts on the mycelial growth compared to the control treatment. Most of the used salts significantly reduced mycelial growth of tested fungus. Salts significantly decreased mycelial growth of Ulocladium chartarum. Sodium carbonate at $4 \%$ was the most effective concentration recorded the lowest value in mycelial growth of fungi, while $1 \%$ potassium nitrate was the least effective one, which about $0.933,6.1$, respectively. Also, Aspergillus niger was significantly affected by $4 \%$ sodium carbonate and $4 \%$ sodium bicarbonate. Aspergillus niger and Geotrichum candidum have a relatively affect than tested fungi. Fusarium 

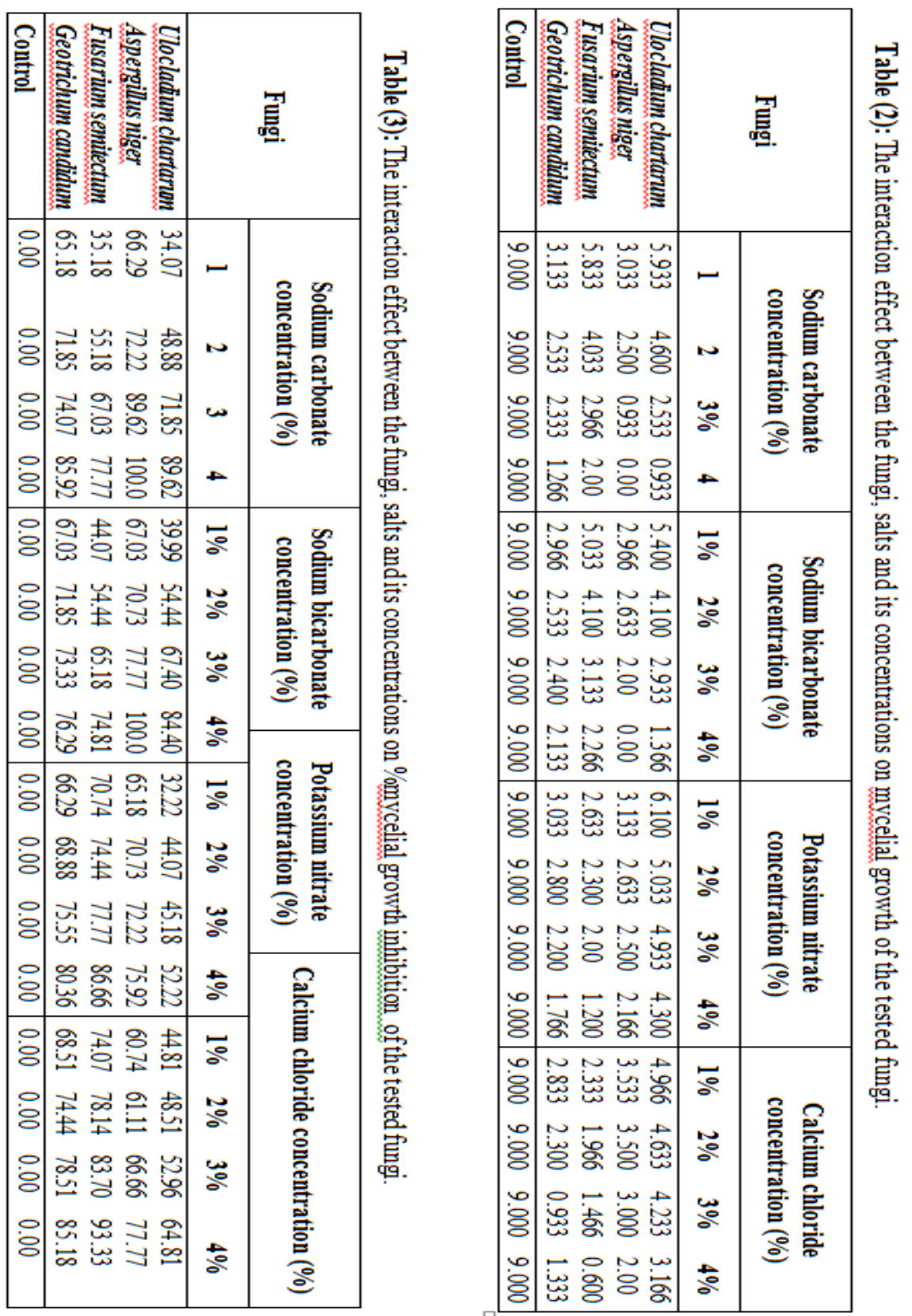
semitectum was affected by the high concentrations $4 \%$ calcium chloride solution. The inhibition percent of mycelial growth for most studied fungi was significantly affected by the high concentrations of the used salts. The results presented in Table (3) indicate a clear impact on \% growth inhibition of fungi and it were $77.77-100 \%, 74.81-100 \%, 52.22-86.66 \%, 64.81-93.33 \%$ for $4 \%$ sodium carbonate concentration, $4 \%$ sodium bicarbonate concentration, $4 \%$ potassium nitrate concentration and $4 \%$ calcium chloride concentration. This increasing recorded 53.60, 61.56, 43.42, 52.77\% for Ulocladium chartarum, 82.03, 78.88, 71.01, 66.57\% for Aspergillus niger, 58.79, 59.63, 77.40, 82.31\% for Fusarium semitectum and the Geotrichum candidum was 74.26, 72.13, 72.77, 76.66\% of carbonate sodium, sodium bicarbonate, potassium nitrate and calcium chloride solutions respectively, compared to the control treatment.

Additionally, the sodium carbonate and/or sodium bicarbonate solutions impacted on inhibition percent of spore germination of tested fungi (Table 4), and the most affective fungp with concentrations of sodium salt's solutions, were Aspergillus niger, Geotrichum candidum and Fusarium semitectum, compared to the control treatments, respectively. Potassium nitrate solution was less effective than other salts solutions, but it effectively inhibited the spore germination of Fusarium semitectum . Aspergillus niger was significantly affected by 3\%, 4\% calcium chloride, while it was not affected by potassium nitrate solutions, as the effect was relatively limited (Table 5). Based on the obtained results, it can be concluded that the optimal concentration of used salts inhibited spore germination $\%$ under the experimental conditions were 4\%, 3\%, 3\%, 3\% (w/v) for sodium carbonate, sodium bicarbonate, potassium nitrate, and calcium chloride respectively. A related context, the significance of interaction was tested between fungi, salts and salts concentrations for mycelial growth, inhibition of mycelial growth, spore germination and \% inhibition of spore germination of fungi. Data presented in Table 6, indicate to statistical analysis of the experiment. The interactions between all studied factors were significant, while the interaction between tested fungi, salts, salt concentrations for inhabitation of mycelial growth of fungi was not significant. these results are consistent with the results of (Arslan et al., 2009(, (Erper et al., 2011), (Latifa et al., 2011), and (Turkkan et al., 2017). In line with the study, several previous studies have also confirmed carbonate and bicarbonate solutions including sodium and potassium nitrate to have inhibitory effects on the mycelial growth of different fungi (Palmer et al., 1997; Palou et al., 2002; Droby et al., 2003; Latifa et al., 2011).

Moreover, many studies demonstrated that sodium carbonate and sodium bicarbonate salts exhibited fungistatic rather fungicidal activity against many 
AMIRA TAWFIK et al.
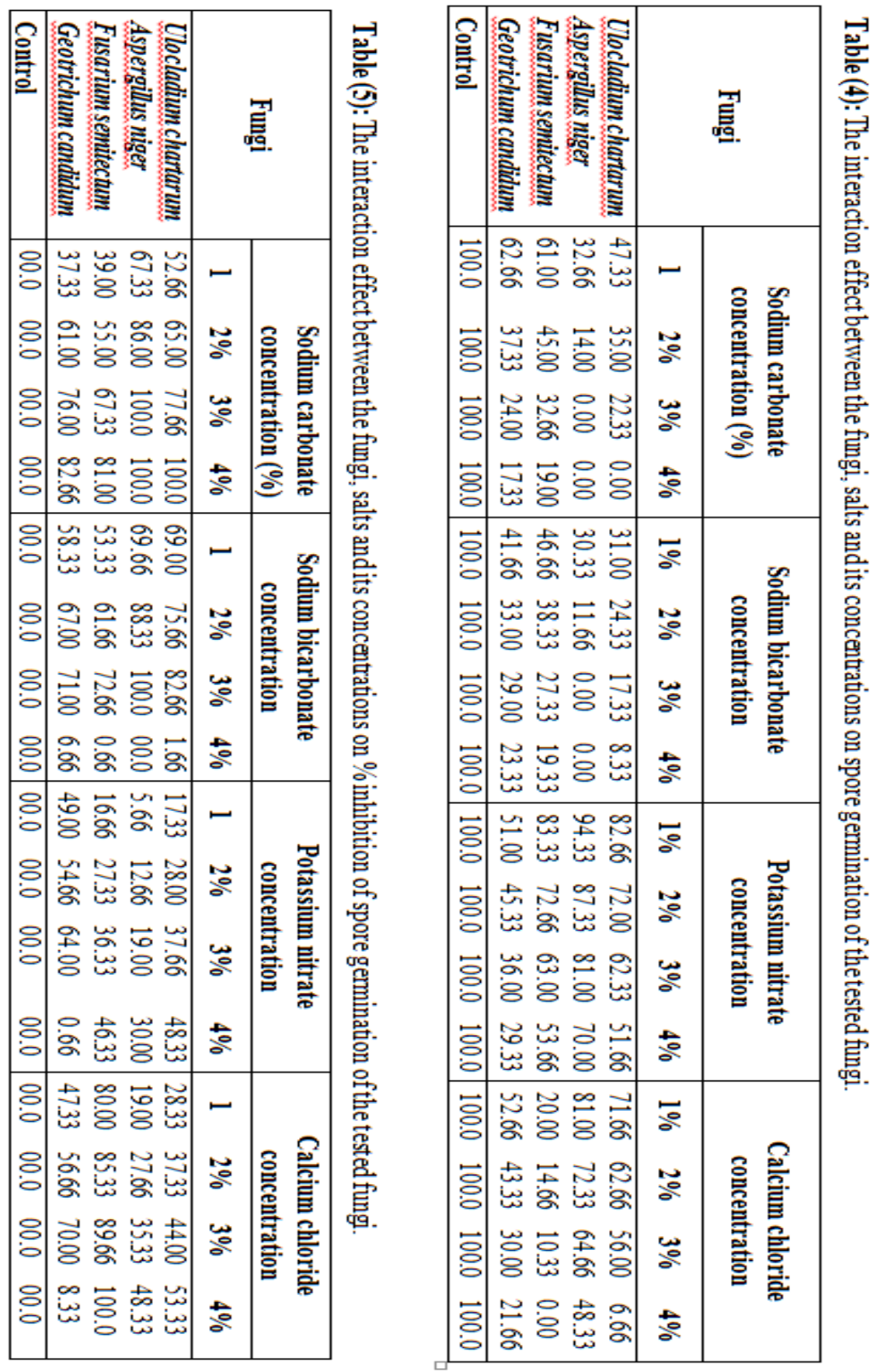
Table (6): Effect of the used salts and its concentrations on the mycelial growth, $\%$ inhibition of mycelial growth, spore germination and \% inhibition of spore germination of the studied fungi.

\begin{tabular}{|c|c|c|c|c|}
\hline Treatments & $\begin{array}{c}\text { Mycelial } \\
\text { growth }\end{array}$ & $\begin{array}{c}\text { Inhibition } \\
\text { of } \\
\text { mycelial } \\
\text { growth } \\
(\%) \\
\end{array}$ & $\begin{array}{c}\text { Spore } \\
\text { germination }\end{array}$ & $\begin{array}{c}\text { Inhibition of spore } \\
\text { germination } \\
(\%)\end{array}$ \\
\hline \multicolumn{5}{|l|}{ Fungi (A) } \\
\hline Ulocladium chartarum & $4.072^{\mathrm{a}}$ & $54.741^{\mathrm{d}}$ & $43.208^{\mathrm{a}}$ & $56.791^{d}$ \\
\hline Aspergillus niger & $2.283^{\mathrm{d}}$ & $74.625^{\mathrm{a}}$ & $42.979^{\mathrm{b}}$ & $56.812^{\mathrm{c}}$ \\
\hline Fusarium semitectum & $2.741^{\mathrm{b}}$ & $69.532^{\mathrm{c}}$ & $37.937^{\mathrm{c}}$ & $62.020^{\mathrm{b}}$ \\
\hline Geotrichum candidum & $2.343^{\mathrm{c}}$ & $73.953^{\mathrm{b}}$ & $36.104^{\mathrm{d}}$ & $63.791^{\mathrm{a}}$ \\
\hline LSD (0.05) & 0.0581 & 0.6450 & 0.9000 & 0.9990 \\
\hline \multicolumn{5}{|l|}{ Salts (B) } \\
\hline Sodium carbonate & $2.785^{\mathrm{c}}$ & $69.046^{\mathrm{a}}$ & $28.145^{\mathrm{c}}$ & $71.750^{\mathrm{b}}$ \\
\hline Sodium bicarbonate & $2.872^{\mathrm{b}}$ & $68.074^{\mathrm{b}}$ & $23.854^{\mathrm{d}}$ & $76.145^{\mathrm{a}}$ \\
\hline Potassium nitrate & $3.045^{\mathrm{a}}$ & $66.152^{\mathrm{c}}$ & $64.789^{\mathrm{a}}$ & $35.229^{d}$ \\
\hline Calcium chloride & $2.737^{\mathrm{d}}$ & $69.579^{\mathrm{a}}$ & $43.500^{\mathrm{b}}$ & $56.291^{\mathrm{c}}$ \\
\hline LSD (0.05) & 0.0581 & 0.6450 & 0.9000 & 0.9990 \\
\hline \multicolumn{5}{|l|}{ Concentrations $(C)$} \\
\hline $1 \%$ & $3.929^{\mathrm{a}}$ & $56.338^{\mathrm{d}}$ & $55.625^{\mathrm{a}}$ & $44.375^{\mathrm{d}}$ \\
\hline $2 \%$ & $3.262^{\mathrm{b}}$ & $63.746^{\mathrm{c}}$ & $44.312^{\mathrm{b}}$ & $55.583^{\mathrm{c}}$ \\
\hline $3 \%$ & $2.593^{\mathrm{c}}$ & $71.175^{\mathrm{b}}$ & $34.750^{\mathrm{c}}$ & $65.208^{\mathrm{b}}$ \\
\hline $4 \%$ & $1.656^{\mathrm{d}}$ & $81.592^{\mathrm{a}}$ & $25.541^{\mathrm{d}}$ & $74.250^{\mathrm{a}}$ \\
\hline LSD (0.05) & 0.0581 & 0.6450 & 0.9000 & 0.9990 \\
\hline \multicolumn{5}{|l|}{ Interactions } \\
\hline $\mathbf{A} \times \mathbf{B}$ & $* *$ & $* *$ & $* *$ & $* *$ \\
\hline $\mathbf{A} \times \mathbf{C}$ & $* *$ & $* *$ & $* *$ & $* *$ \\
\hline $\mathbf{B} \times \mathbf{C}$ & $* *$ & $* *$ & $* *$ & $* *$ \\
\hline $\mathbf{A} \times \mathbf{B} \times \mathbf{C}$ & $* *$ & NS & $* *$ & $* *$ \\
\hline \multicolumn{5}{|l|}{ LSD of interactions: } \\
\hline $\mathbf{A} \times \mathbf{B}=$ & 0.0957 & 1.0639 & 1.7470 & 1.8800 \\
\hline $\mathbf{A} \times \mathbf{C}=$ & 0.9300 & 10.341 & 3.9180 & 1.1520 \\
\hline $\mathrm{B} \times \mathrm{C}=$ & 1.2040 & 13.380 & 10.225 & 10.292 \\
\hline $\mathbf{A} \times \mathbf{B} \times \mathbf{C}=$ & 1.0648 & - & 10.618 & 10.099 \\
\hline
\end{tabular}


fungi (Punja and Grogan, 1982; DePasquale and Montville, 1990; Palou et al., 2002; Latifa et al., 2011). The inhibitory effect of bicarbonate salts on fungi was probably due to the reduction in fungal cell turgor pressure which resulted in the collapse and shrinkage of hyphae and spores, consequently, the inability of fungi sporulation (Fallik et al., 1996). In another study, the results confirmed that a solution of potassium nitrate increased inhibition of the growth of some fungi on soybean plants and it was due to indicate that potassium accumulation in inhibitory growth sites (Sugimoto et al., 2009). Türkkan et al. (2017) confirmed that carbonate and carbonate salts have broad-spectrum antimicrobial properties and are generally recognized as safe compounds which do not require expensive testing and validation by regulatory agencies. Therefore, they are very promising candidates for postharvest diseases, especially in fresh commodities to which the application of synthetic fungicides is banned such as sweet pepper. Additionally, our results are consistent with the results of Stošić et al. (2014), who confirmed that calcium chloride salt has a great effect and important role in inhibiting of the growth of some fungi.

\section{CONCLUSION}

Based on the obtained results and it confirmed a significant effect for most used salts solutions especially sodium salts. It significantly inhibited growth of the tested fungi. Also, the effective concentrations of these salt's solutions under the experiments study conditions to inhibit the growth of Ulocladium chartarum, Aspergillus niger, Fusarium semitectum and Geotrichum candidum were 4, 3, 3, $3 \%(\mathrm{w} / \mathrm{v})$ for sodium carbonate, sodium bicarbonate, potassium nitrate and calcium chloride, respectively.

\section{REFERENCES}

Ademoyegun, O.T., Fariyike T. A. and AminuTaiwo R. B. (2011). Effects of poultry dropping on the biologically active compounds in Capsicum anuum L (var. Nsukka yellow). Agricultural and Biology J. North America, 2 (4): $665-672$.

Aharoni, Y., Fallik, E, Copel, A., Gil, M., Grinberg, S. and Klein. J. D. (1997). Sodium bicarbonate reduces postharvest decay development on melons. Postharvest Biol. Technol., 10:201 - 206.

Ajith, P. S. and Lakshmidevi, N. (2011). Effects of sodium and potassium salts on Colletotrichum capsici instant of anthracnose on bell pepper. $J$. Agricultural Technology, 7(2): 423 - 430. 
Arimoto, Y., Homma Y. and Misato T. (1997). The effect of sodium hydrogen carbonate on the occurrence of citrus storage diseases. J. Pest. Sci., 2: 163167.

Arslan, U., Kadir I., Vardar C. and Karabulut, O. A. (2009). Evaluation of antifungal activity of food additives against soil-borne phyto-pathogenic fungi. World Journal of Microbiology and Biotechnology, 25: 537 - 543.

Ashilenje, D. S., (2013). Learn How to Grow Pepper. Phoenix publishers Limited Nairobi, Kenya.

Bae, H., Jayaprakasha G. K., Jifon J. and Patil B. S. (2012). Variation of antioxidant activity and the levels of bioactive compounds in lipophilic and hydrophilic extracts from hot pepper (Capsicum spp.) cultivars. Food Chemistry, 134: 1912 - 1918.

Barnett, H.L. and Hunter, B.B. (1998). Illustrated Genera of Imperfect Fungi. APS Press Pp. 163 - 193.

Berke, T. (2002). The Asian Vegetable Research and Development Center Pepper Project. Proceedings of the $16^{\text {th }}$ International Pepper Conference, Tampico, Mexico. November 10-12, Tamaulipas, Mexico. pp1-16.

Campanella, V., Ippolito A. and Nigro F. (2002). Activity of calcium salts in controlling Phytophthora root rot of citrus. Crop Protection, 21: $751-756$.

DePasquale, D. A., El-Nabarawy, A., Rosen, J. D. and Montville, T. J. (1990). Ammonium bicarbonate inhibition of mycotoxigenic fungi and spoilage yeasts. J. Food Protection, 53: $324-328$.

DePasquale, D. A., Montville, T. J., (1990). Mechanism by which ammonium bicarbonate and ammonium sulfate inhibit mycotoxigenic fungi. Appl. Environ. Microbial., 56:3711 - 3717.

Droby, S., Wisniewski M. E., Cohen L., Weiss B., Touitou D., Eilam Y. and Chalutz E. (2003). Influence of $\mathrm{CaCl}_{2}$ on Penicillium digitatum, grapefruit peel tissue, and biocontrol activity of Pichia guilliermondii. Plant Dis., 87: 310-315.

Duncan, D. B., (1955). Multiple-range and multiple-F tests. Biom., 11, 1- 42.

Ekhuemelo, C., Isa Bwala R. and Terfa D. (2018). Effect of plant extracts on the postharvest quality and management of pepper anthracnose incited by Colletotrichum capsici (Synd) Butler and Bisby on pepper (Capsicum frutescens L.) fruits. Asian J. Agricultural and Horticultural Research, 1(2): $1-7$.

El-Mougy, N. S. and Abdel-Kader M. M. (2009). Salts application for suppressing potato early blight disease. J. Plant Protection Research, 49(4). 
Elsherbiny, A. E. and A. Y. El-Khateeb. (2012). Effect of organic and inorganic salts on mycelial growth, sporulation and spore germination of potato postharvest pathogens J. Plant Prot. and Path., Mansoura Univ., 3(12): $1353-1364$.

Erper, I., Turkkan M., Karaca G. H. and Kilic G., (2011). Evaluation of in vitro antifungal activity of potassium bicarbonate on Rhizoctonia solani AG 4 HG-I, Sclerotinia sclerotiorum and Trichoderma sp. African J. Biotechnology, 10 (43): $8605-8612$.

Fallik, E., Grinberg S. and Ziv O. (1996). Potassium bicarbonate reduces postharvest decay development on bell pepper fruits. J. Hort. Sci., 71: 121127.

Fawole, M. O. and Oso, B. A. (1988). Laboratory Manual of Microbiology, Spectrum Books Ltd, Ibadan. pp. $14-18$.

Hasan, M. F, Mahmud T. M. M, Kadir J., Ding P. and Zaidul I. S. M. (2012). Sensitivity of Colletotrichum gloeosporioides to sodium bicarbonate on the development of anthracnose in papaya (Carica papaya L. cv. Frangi). Australian J.Crop Science, 6 (1):17-22.

Horst, R. K., Kawamoto S. O. and Porter L. L. (1992). Effect of sodium bicarbonate and oils on control of powdery mildew and black spot of roses. Plant Dis., 76: 247-251.

Ilić, S. Z., Trajković, R., Perzelan, Y., Alkalai-Tuvia, S. and Fallik, E. (2012). Influence of 1-methylcyclopropene (1- MCP) on postharvest storage quality in green bell pepper fruit. Food and bioprocess technology, 5: 2758-2767.

Janisiewicz, W. J. and Peterson D. L. (2005). Experimental Bin drenching system for testing biocontrol agents to control postharvest decay of apples. Plant Dis., 89: 487-490.

Karabulut, O. A., Bursa G. and Mansour M. (2003). Near-harvest applications of Metschnikowia fructicola, ethanol and sodium bicarbonate to control postharvest diseases of grape in central California. Plant Dis., 87: 1384 1389.

Latifa A., Idriss T., Hassan B., Amine S. M., El Hassane B. and Abdellah A. B. A., (2011). Effects of organic acids and salts on the development of Penicillium italicum: the causal agent of citrus blue mold. Plant Pathol J., 10: $99-107$.

Lilly, V. G., and H. L. Barneiq. (1951). Physiology of The Fungi. McGraw-Hill Book Co., New York, xii + 464 pp.

Lindsay, R. C. (1985). Food Additives. Chapter 10. In: Fennema OR (ed) Food chemistry. Marcel Dekker, Inc., New York. 
Maalekuu, K.; Elkind, Y.; Tuvia-Alkalai, S., Shalom, Y. and Fallik, E. (2003). Quality evaluation of tree sweet pepper cultivars after prolonged storage. Advance in Horticultural Science, 17: 187 - 191.

McLaughlin, R. J.; Wisniewski M. E., Wilson C. L. and Chalutz E. (1990). Effect of inoculum concentration and salt solutions on biological control of postharvest diseases of apple with Candida sp. J. Phytopathology, 80: 456 461.

Palmer, C. L., Horst R. K. and Langhans R.W. (1997). Use of bicarbonates to inhibit in vitro colony growth of Botrytis cinerea. Plant Disease, 81:14321438 .

Palou, L., Usall, J., Smilanick, J. L., Aguilar, M. J. and Vinas, I. (2002). Evaluation of food additives and low-toxicity compounds as alternative chemicals for the control of Penicillium digitatum and Penicillium italicum on citrus fruit. Pest Manag. Sci., 58: 459 - 466.

Punja, Z. K. and Grogan, R. G., (1982). Effects of inorganic salts, carbonatebicarbonate anions, ammonia, and the modifying influence of $\mathrm{pH}$ on sclerotial germination of Sclerotium rolfsii. Phytopathology, 72:635 - 639 .

Smilanick, J. L., Mansour M. F. and Sorenson D. (2006). Pre- and postharvest treatments to control green mold of citrus fruit during ethylene degreasing. Plant Dis., 90: 89 - 96.

Smilanick, J. L., Margosan D. A., Mlikota F., Usall J. and Michael I. F. (1999). Control of citrus green mold by carbonate and bicarbonate salts and the influence of commercial postharvest practices on their efficacy. Plant Dis., 83: 139 - 145 .

Stošić, S., Stojanović S., Milosavljević A., Pfaf Dolovac E. and Živković S. (2014). Effect of calcium salts on postharvest fungal pathogens in vitro. Plant Protection J., 65(287): 40 - 46.

Sugimoto, T., Watanabe K., Furiki M., Walker D. R., Yoshida S., Aino M., Kanto T. and Irie K. (2009). The effect of potassium nitrate on the reduction of Phytophthora stem rot disease of soybeans, the growth rate and zoospore release of Phytophthora sojae. J. Phytopathol., 157:379-389.

Turkkan, M. (2013). Antifungal effect of various salts against Fusarium oxysporum F. sp. cepae, the causal agent of Fusarium basal rot of onion. Agricultural Sciences, 19: 178 - 187.

Türkkan, M., Özcan M. and Erper İ. (2017). Antifungal effect of carbonate and icarbonate salts against Botrytis cinerea, the causal agent of grey mold of kiwifruit. Akademik Ziraat Dergisi, 6(2):107 - 114. 
Ziv, O. and Zitter T. A. (1992). Effects of bicarbonates and film-forming polymers on cucurbit foliar diseases. Plant Dis., 76: 513 - 517.

\section{تأثير بعض الأملاح عل نمو الميسليم وإنبات جراثيم الفطريات التي تصيب ثمار القلقل الحلو ما بعد الحصاد}

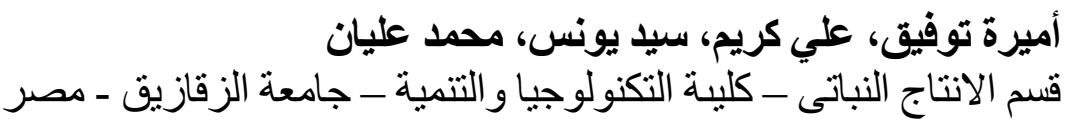

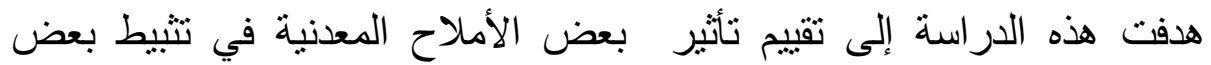

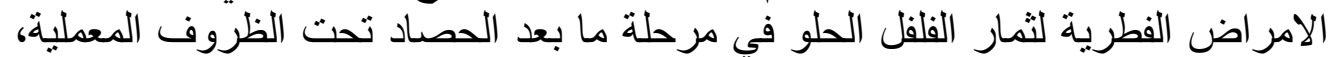

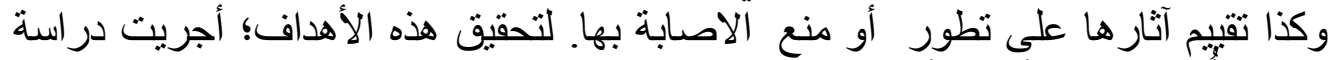

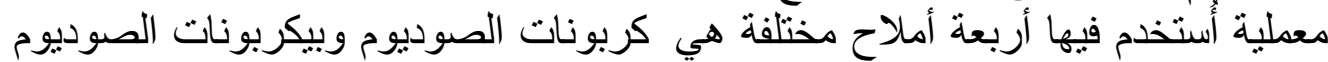

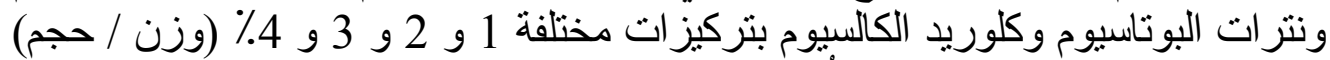

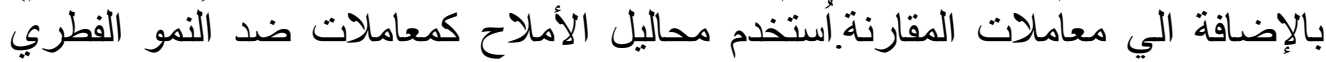
و إنبات الجراثيم في فطريات، Aspergillus Niger ، Ulocladium chartarum

.Geotrichum candidum ، semitectum Fusarium

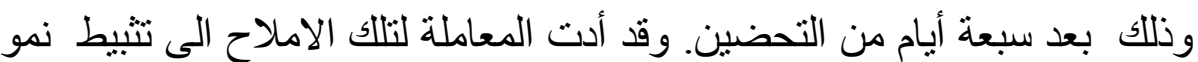

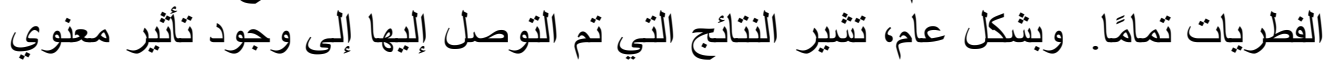

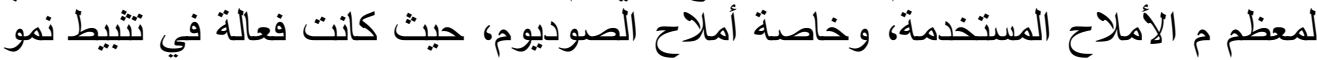

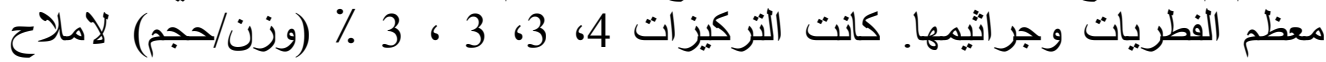

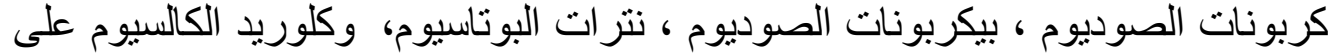

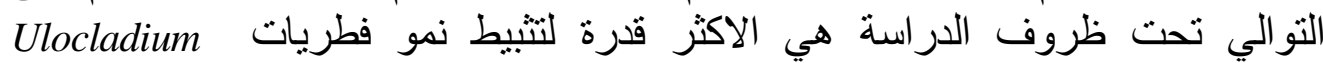
. candidum Geotrichum ، Fusarium semitectum ، Aspergillus Niger ، chartarum

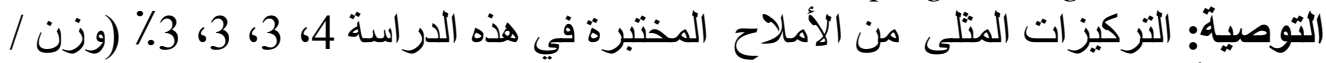

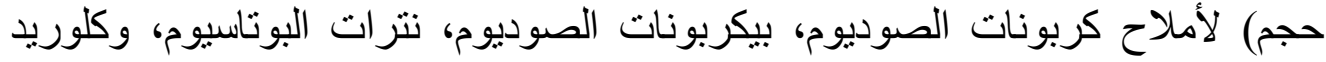

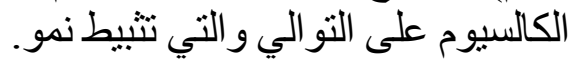
الكلمات الدالة: النمو الفطري. إنبات الجر اثثي. الفلفل الحلو. الاملاح المعدنية. 
